Primljen / Received: 25.3.2016. Ispravljen / Corrected: 23.6.2016.

Prihvaćen / Accepted: 20.8.2016.

Dostupno online / Available online: 10.2.2017.

\section{Management aspects of road pavement rehabilitation}

Author:

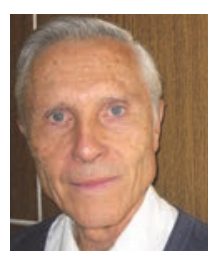

Prof. László Gáspár, PhD. CE

KTI Institute for Transport Sciences NonProfit Ltd

Budapest, Hungary

gaspar@kti.hu

\begin{abstract}
László Gáspár
\section{Management aspects of road pavement rehabilitation}

The optimization of a pavement management system necessitates the knowledge on the actual values of pavement condition parameters, actual pavement condition improvement as related to the use of various rehabilitation strategies, and scope of pavement deterioration before and after rehabilitation. The data for six pavement condition parameters (bearing capacity, unevenness, rut depth, macro texture, micro texture, and pavement surface defects) are used to enable improvement of relevant technical specifications and further development of the network-level pavement management system.
\end{abstract}

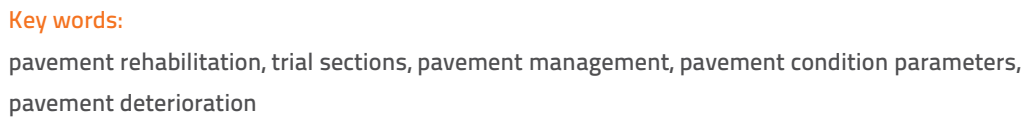

Prethodno priopćenje

\section{László Gáspár}

\section{Obnavljanje cestovnih kolnika s obzirom na sustav održavanja}

Optimalizacija sustava gospodarenja kolnicima zahtijeva podatke o stvarnim vrijednostima parametara stanja kolnika, stvarnom poboljšanja stanja kolnika s obzirom na primjenu različitih strategija obnove te opsegu oštećenja kolnika prije i nakon obnove. Podaci o šest različitih parametara stanja kolnika (nosivost, ravnost, dubina kolotraga, makrotekstura, mikrotekstura, oštećenja površinskog sloja kolnika) upotrijebljeni su za poboljšanje odgovarajućih tehničkih specifikacija i daljnji razvoj sustava gospodarenja kolnicima na razini prometne mreže.

Ključne riječi:

obnavljanje kolnika, pokusne dionice, upravljanje kolnikom, parametri stanja kolnika, oštećenje kolnika

Vorherige Mitteilung

László Gáspár

Erneuerung von Straßenfahrbahnen im Hinblick auf Instandhaltungssysteme

Für die Optimierung des Verwaltungssystems für Straßenfahrbahnen müssen Werte der Parameter des Fahrbahnzustandes, sowie Informationen zur Verbesserung des Fahrbahnzustandes im Hinblick auf die Anwendung verschiedener Strategien und zum Umfang der Beschädigungen vor und nach der Erneuerung vorhanden sein. Informationen zu sechs verschiedenen Parametern des Fahrbahnzustandes (Tragfähigkeit, Ebenheit, Spurrinnentiefe, Makrotextur, Mikrotextur, Beschädigung der Fahrbahnoberfläche) wurden verwendet, um entsprechende technische Spezifikationen zu verbessern und Verwaltungssysteme für Fahrbahnen auf Straßennetzniveau weiterzuentwickeln.

Schlüsselwörter:

Erneuerung von Straßenfahrbahnen, Testabschnitte, Fahrbahnverwaltung, Parameter des

Fahrbahnzustandes, Fahrbahnbeschädigung 


\section{Introduction}

Highway networks of industrialized countries are nowadays generally completed, and so only some city by-passes or expressway sections still await construction. However, continuous increase in traffic volume and intensity, together with ever worsening climatic effects (climate change!), generate serious challenges and require additional efforts by the owners and operators of roads to provide and maintain superior pavement conditions, and to meet users' expectations regarding longer durability [1].

Synergistic effects of traffic and climatic loads present road operators (and also road owners) with highly demanding tasks. In addition to professional routine maintenance of roads, the design and construction features of structural pavement rehabilitation activities are of major importance, contributing greatly to an efficient and economic management of road pavements. A well-functioning PMS can inter alia be utilized for optimum timing of pavement condition improvement activities on road sections [2].

The utilization of standard rules for selecting a rehabilitation strategy (treatment) allows adoption of a consistent approach to planning, and definition of activities, making up the road administration practice [3]. This helps to ensure that funds are spent to the greatest effect and that each road receives a fair share of the budget. These rules should reflect standards and intervention levels defined in the policy framework. A distinction can be made between scheduled and condition-responsive rules. Under normal conditions, routine maintenance activities of cyclic nature are usually carried out on a scheduled basis. The schedule for undertaking cyclic activities often depends on the road class, in order to reflect the "level of service" considerations. Treatment selection issues concerning scheduled methods are mainly related to engineering decisions about the treatment method itself, rather than to fundamental decisions about the kind of treatment to be applied [4].

Whereas scheduled rules are relatively easy to specify and implement, there are several methods for specifying conditionresponsive rules. These involve the use of intervention levels which, when arrived to and exceeded, trigger the onset of different treatments. Main pavement-condition indicators are longitudinal and transverse unevenness, surface distress, structural capacity, pavement texture, and friction. Any method used requires a physical inspection, in order to determine the severity and extent of defectiveness.

The efficiency levels of various pavement rehabilitation methods basically differ depending on a lot of parameters including initial pavement and sub-grade condition, quality of basic materials to be used for pavement rehabilitation, level of rehabilitation design (selection of an "optimum" intervention method), quality of construction, level of timeliness and professionalism in maintenance activities, traffic load characteristics, and environmental load. Sixty trial sections, each 500 m in length, selected from the Hungarian national highway network, have been monitored annually since 1991. Since the majority of these trial sections were rehabilitated at least once over the past 25 years, the actual characteristics of the Hungarian road management practice can be collected and scrutinized, so as to utilise this information in road management.

\section{Hungarian Pavement Management Systems}

Several Pavement Management Systems have been developed in Hungary over the past decades [5].

\subsection{MPMS (Network-level pavement management system)}

The first Hungarian network-level PMS was created by the Institute for Transport Sciences (KTI) and Technical University of Budapest $[6,7]$. The methodology used is based on the Markovtype transition probability matrices, since it is a clear system and as it does not require longer condition data time series as a precondition. Matrix variables are: pavement type, traffic level, and intervention type. Pavement types are: asphalt concrete and asphalt macadam. Traffic classes are: max. 3,000 PCU/day, 3,001 to 8,000 PCU/day, min. 8,001 PCU/day (PCU = passenger car unit). The following intervention variants are considered: routine maintenance, surface dressing, and asphalt overlay. Instead of the internationally widespread "do-nothing" variant, a "routine maintenance" - constituting the slightest intervention variant - was applied. In the light of the above facts, $2 \times 3 \times 3=18$ matrices could theoretically be compiles. However, two of them, i.e. surface dressing above 8,000 PCU/day for both pavement types, were excluded for technological reasons. Thus, sixteen matrices in total were compiled.

The rows and columns of the Markov transition probability matrices are formed by pavement condition variants. The following pavement condition parameters are selected: 5-level bearing capacity score, 3-level unevenness, 5-level pavement defects score. So, theoretically, $5 \times 5 \times 3=75$ condition variants would be available. Relatively rare condition variants (maximum $10 \mathrm{~km}$ in the whole national road network) are not considered separately, but are combined with similar, sufficiently widespread, condition variants. Finally, 41 condition variants have been considered in the model. Each matrix element relies on actual or interpolated domestic data. A separated row-vector under the matrix indicates the unit cost for $1 \mathrm{~m}^{2}$ for the given intervention type performed. Each matrix measures $41 \times 41$. The horizontal axis indicates condition variants in the first year, whereas the vertical axis shows the expected condition variant distribution in the second year. The sum of each column is 1.0 [8]. The PMS model can be used to solve any of the following three tasks:

- determination of funds needed to ensure a given condition level based on some optimum criteria,

- regional and functional distribution of a certain amount of money under constraints and given optimum criteria, and 
- evaluation of losses arising from modification of the optimized funds distribution.

\subsection{Other pavement management system models}

A project-level Pavement Management System (PMS) was also developed for urban road networks [9, 10]. In addition, a special Motorway Pavement Management System (APMS) was developed in Hungary [11]. Due to "childhood diseases" of the MPMS-model, the HUPMS-model [11] has been developed using the optimisation procedure of MPMS and the model structure of HIPS [12] with:

- several (max. 10) time periods,

- asphalt concrete and asphalt macadam pavement types,

- 3 traffic categories,

- 4 condition parameters (unevenness, bearing capacity, rut depth, surface defects),

- combined target function,

- max. 8 intervention types.

In the long-term model, the optimal solution (Markov-stable condition).is sought for the distribution of pavement conditions across the network, which can be attained after optimum interventions. The target function is the minimum of the sum of agency and user costs (i.e. the total social optimum). The Markov transition probability matrices are used for modelling the deterioration processes. The mathematical model contains the Markov stability related condition levels, condition level distribution in initial and later years, proportions of the different condition levels, cost limitations, etc. For a multi-stage model, one of the objectives could be to reach a stable model result through a several-year approximation.

\section{Factors influencing pavement deterioration}

The evaluation of pavement performance involves the study of functional behaviour and structural capacity of a section [13]. The durability (favourable performance), as a major expectation from a newly-built or rehabilitated road pavement, is influenced by a lot of parameters. Major parameters contributing to road durability (resistance to deterioration) are briefly presented below.

The most important function of the road pavement is to withstand synergistic mechanical and environmental loads without suffering excessive deformation. The layered structure of the pavement is meant to ensure that the load is spread out below the tyre in such a way that the resultant stress at the bottom layer of the pavement structure, the sub-grade, is low enough not to cause damage [14].

Since pavement structures are exposed to environmental influences, a very important factor in the design of pavements is the consideration of water, which could be coming from rain/ snow and/or from the ground. A basic requirement for designing a proper (durable) pavement is to provide adequate drainage for both surface and subsurface water [15]. While designing, an adequate thickness should be assigned to each layer, so that desirable properties are obtained in the most cost-effective way. Once the pavement structure is properly designed, it must be adequately constructed. To ensure this, the material must be properly placed, cured (if needed) and compacted, so that it has desirable qualities, such as the density and/or stiffness. While selecting materials and designing the mix and the structure, it is important to take into account the workability. Quality control must be carried out during construction to ensure strict adherence to specifications, and hence a high and uniform quality over the entire duration of the project.

The quality of a highway pavement starts to deteriorate from the day one after its construction. Even though a properly designed and constructed pavement will not deteriorate so as to cause total failure within its design life, the entire pavement will in fact become worthless at the end of its design life, if no maintenance is performed. The best approach is to regularly perform maintenance operations (e.g. surface dressing applied at every 4-5 year intervals keeps the asphalt from excessive hardening that would otherwise lead to extensive cracking). Although these actions do not specifically increase the design life, they can certainly prevent its rapid deterioration. In most cases, once built, a pavement can be "recycled" at the end of its design life for an almost infinite number of times, by reusing the existing materials either solely or in combination with new materials. Rehabilitation of pavements is a costly process. A proper inventory of the condition of different pavements must be properly kept and utilized so as to determine the time/order in which different pavement sections should be rehabilitated. This is important partly because there is never enough funding for rehabilitation of every candidate section, and partly because different roads deteriorate at different rates [16], and hence are in different conditions at any given time. Besides, the pavement performance prediction using sophisticated methodology [17] could have an important role in an economical design of a durable highway pavement (rehabilitation).

\section{25-year trial section monitoring}

\subsection{Performance data collection methods}

The typical investigation methods for getting performance information to be used in pavement (rehabilitation) design are as follows [18]:

- Computerized performance models

- Laboratory test series

- Accelerated loading tests

- Trial (experimental) section monitoring

\section{Computerized performance models}

Special computerized (e.g. finite element) models are available worldwide to forecast the performance of various pavement structure variants. The expected deterioration rate of selected 
- eventually critical - condition parameters (stresses, strains, deformation etc.), resulting from cumulative synergistic effect of mechanical and environmental loads, can be obtained after a relatively short running time as the output of the model. The real challenge for the engineer is realistic selection of programme inputs, i.e. mechanical properties (such as E-modulus) of the pavement structure material in question. It is hard to choose each characteristic deterioration mode to be considered in the calculation. This approach does not take much time but the resulting level of accuracy is rather limited due to the generalization and simplification of inputs considered in the model.

\section{Laboratory test series}

Another methodology for forecasting performance of pavement materials is to produce test specimens and carry out special laboratory investigations. Even if the planned material composition is used in laboratory test series, it is important to select the investigation methods that can simulate as accurately as possible characteristic deterioration modes for the structure in question. The main limitations of this relatively quick methodology are: environmental loads cannot be considered at all or at least not realistically, and the relatively small size of laboratory samples results in different performance compared to that of the real-size road element.

\section{Accelerated laboratory tests}

A lot of countries operate accelerated loading testing (ALT) facilities (circular tracks, linear tracks with load moving to and from, etc.) which are usually open-air but a couple of them were made in buildings. In some cases, the artificial, (almost) continuous loading is performed by multi-axle, heavy trucks; however, continuously moving, highly loaded wheels or axles are more often used for this purpose. Several technological variants - including reference one(s) - can be loaded simultaneously allowing direct comparison of their performances. Another positive feature of this performance prediction procedure is that no previous "speculation" on the expected pavement deterioration modes is needed; the actual, experienced change in the initial condition parameter levels provides information about the critical mode(s). However, some 10-year highway traffic load can be performed in ALTS in a month or two; the repeated environmental load of a highway section under "normal" traffic cannot be simulated when using accelerated loading facilities. (The ALTs in buildings can have the possibility to change air temperature, relative humidity, subgrade moisture content, etc., but realistic simulation is not possible). It is rather expensive to build and operate such accelerated loading facilities.

\section{Trial (experimental) section monitoring}

It is obvious that the most reliable prediction of pavement performance can be obtained by the use of experimental (trial) sections, provided that the following important preconditions are met: careful selection of the location and sufficient length of experimental section(s); selection of appropriate reference section; professional and thorough pavement design; wellequipped contractor; effective quality management including continuous and strict independent quality control; careful planning of monitoring activities for the trial and reference sections including the condition parameters investigated, use of suitable measuring techniques (devices), durable marking of point-like measuring spots if any (if non-continuous measuring techniques are used); selection of measuring frequency (typically every year); sophisticated evaluation of the condition data time series obtained. Even if every precondition listed above is satisfied, and so a reliable performance prediction can be expected, the time-consuming nature of the methodology cannot be ignored.

\subsection{Characteristics of Hungarian trial sections}

Sixty sections forming part of the national highway network have been systematically monitored in Hungary since 1991 [19]. A special methodology [20] has been utilised in the selection of the trial sections for long-term monitoring. The main goal of systematic pavement condition evaluation is to develop deterioration models that may be considered as representative of the whole national highway network. That is why typical Hungarian road characteristics are represented by the trial sections. The following pavement structure categories have been chosen: semi rigid (cementitious base/subbase); flexible (bituminous base/sub-base); super-flexible, and asphalt macadam type (unbound base/subbase) structures. The traffic categories selected are: max. 3000 PCU/day; 3000-8000 PCU/ day; min. 8001 PCU/day, (PCU = passenger car unit). Sub-grade soil bearing capacity classes are: max. 4 \% CBR-value, 5-7\% CBR-value, min. $8 \%$ CBR-value.

The actual number of possible variants (pavement type traffic - subsoil) in the entire network was considered when deciding on the number of various "road categories". Some very rare categories have been combined with similar but more frequent ones. The road data bank information was utilised for the selection of candidate trial sections. Additional data were gathered from regional highway directorates, and every section was visited by researchers so that local conditions can properly be established. Fourteen road section categories were chosen. Typically, 3-6 representative sections were selected per category, thus bringing the total number of trial sections to 60 . Yearly condition evaluation has been carried out at 500 m-long sections on the right-side traffic lane.

\subsection{Data collection methodology}

Each year, the following condition parameters have been evaluated and analysed on test sections:

- unevenness - American term: roughness - (IRI, International Roughness Index using laser RST)

- rut depth (using laser RST) 
- macro texture (using laser RST characterized by dimensionless factors)

- micro texture (using laser RST characterized by dimensionless factors)

- bearing capacity (using KUAB falling weight deflectometer)

- surface defects (visual evaluation aided by ROAD MASTER keyboard apparatus).

The measurements have been carried out, as much as practicable, at the same points or along the same lines (the outer rut lines) every year, and also at the same time of year (April-May). IRI-values are automatically computed by the software of the Road Survey Tester.

\section{Maintenance effect evaluation based on trial section monitoring}

\subsection{Data collection}

The trial section monitoring has been performed in Hungary since 1991. During this 25-year period, a considerable share of sections have deteriorated to such an extent that surface dressing, resurfacing or strengthening has become necessary. The decision was made to continue with the regular condition evaluation since the additional survey could provide other kinds of useful information. The condition parameter levels in the years before and after the intervention can be utilised for determining the actual condition improving effect of various major maintenance techniques. Furthermore, the continuation of monitoring for several more years can provide information about deterioration trends after the intervention, which can be compared to the tendencies during the former life-cycle(s) [23]. Between 1991 and 2015, 55 pavement sections (92\% of the 60 trial sections) were rehabilitated. Altogether 37 projects with pavement strengthening, 9 with thin asphalt layers, and 20 with double bituminous emulsion surface dressings, were realized (two interventions were made on eleven sections during this period). In the group "pavement strengthening", the overlaying above $40 \mathrm{~mm}$ asphalt layer thickness is taken into consideration. The effects of such strengthening on surface defects, unevenness, rut depth, macro texture, and micro texture, were analysed. Mainly the change in surface defects, and in macro and micro texture, were evaluated for the trial sections with surface dressing [24].

Trial section condition data can be used for determining the actual Hungarian practices regarding condition level before rehabilitation, and the actual condition improving effect of pavement rehabilitation. These data can also be used for comparing deterioration trends before and after rehabilitation. The major goal of monitoring activities on 60 trial sections is the development of performance models, i.e. average (typical) deterioration curves. The performance models for individual road section categories can be obtained by putting regression curves on the points representing condition parameter levels as a function of time (similar curves were determined as a function of traffic, expressed in PCU).

The performance models of each road category and each condition parameter have been determined repeatedly, every year, utilising also the latest condition information. The Box and Whisker plot was applied to select and to exclude the outliers of the data series [22].

\subsection{Condition level before rehabilitation}

Pavement management systems usually utilize intervention levels that are the given condition parameter values below which pavement operation is no more economical [25]. Of course, these levels differ by road type (e.g. $2.5 \mathrm{~m} / \mathrm{km}$ IRIvalue on motorways). Since actual intervention level values constitute a basic PMS information, their validation is of utmost importance. The long-term monitoring of trial sections offered a good opportunity for this validation.

Another important fact should also be considered: deterioration rates of various pavement condition parameters are usually not identical. When the "most rapid" one, i.e. the critical parameter, reaches its intervention level - and thereby necessitates pavement rehabilitation - other parameters are still at a relatively appropriate level, at which the condition improving rehabilitation actions are not yet needed (although typical rehabilitation techniques improve actual condition of all parameters including the ones that are still at an acceptable level [4]). The analysis of trial section performance data also enables gathering information on critical condition parameters for different road types that can be considered as a basic knowledge for further development of the national pavement design theory and practice. Similarly, the actual levels of critical parameters before the condition improving actions coming from trial section monitoring also constitute an important piece of information.

The age of trial section wearing courses before strengthening ranged between 4 and 31 years. The most frequent pavement age varied from 11 to 15 years; however, 6 cases with 6-10 years, 4 cases with 16-20 years, and 5 cases between 20-24 years, were registered (the pavement ages of less than 6 years and more than 24 years are exceptional).

The longitudinal unevenness, IRI-values of trial section pavements to be rehabilitated were usually in the range of $1.1-2.6 \mathrm{~m} / \mathrm{km}$ (the only exception was an asphalt macadam pavement with $7.1 \mathrm{~m} / \mathrm{km} \mathrm{IRI-value).}$

In case of thin asphalt layers, old wearing course ages and IRIvalues were similar to those of pavement strengthening.

The rut depth on trial sections before pavement strengthening varied from 1.5 to $14.8 \mathrm{~mm}$. It is obvious that in the cases with the rut depth of 1.5-5.0 mm, some other pavement condition parameter was the critical one necessitating rehabilitation. The condition data time series of trial sections have validated previous expectations according to which no thin asphalt layer can be effective if the rut depth on the old pavement surface exceeds $10 \mathrm{~mm}$. 
The initial longitudinal unevenness of trial sections before surface dressing amounted to $1.8-3.6 \mathrm{~m} / \mathrm{km} \mid \mathrm{RI}$-value on main roads, and to $4.0-6.0 \mathrm{~m} / \mathrm{km}$ on secondary roads. The initial average rut depth amounted to $2.0-4.5 \mathrm{~mm}$ on main roads, and 2.0-9.0 mm on secondary roads. The rather wide range of macro texture of the "old" pavement surface varied between 0.20 and 0.65 . The micro texture mass proved to be more homogeneous and varied from 0.13 to 0.38 .

\subsection{Actual condition improving effect of pavement rehabilitation}

The effect of pavement strengthening - typically 4-6 cm overlay without recycling - on visual condition (characterisation of surface defects) is shown in Figure 2. It can be seen that the original medium-poor condition level (scores 3-5) changes into excellent level (score 1) or good level (score 2). The five points in Figure 1 actually represent information about 16 sections, since the variant $4 \rightarrow 1$ occurs seven times, and $5 \rightarrow 1$ three times, while the variants $4 \rightarrow 2,3 \rightarrow 1$ and $5 \rightarrow 2$ occur two times.

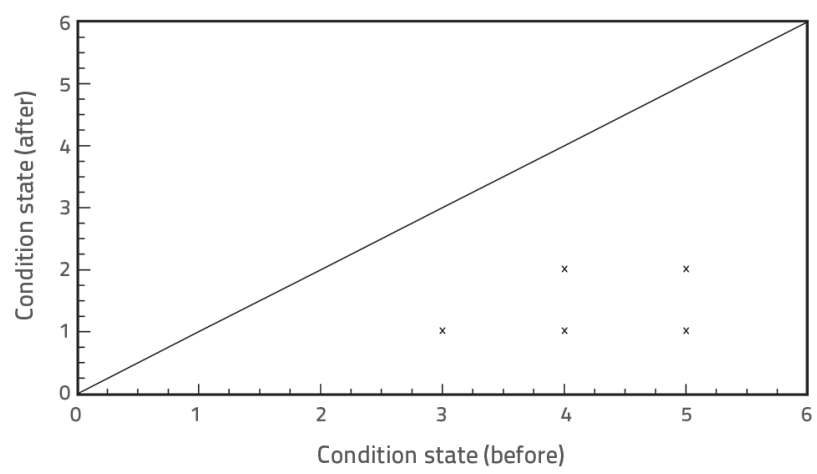

Figure 1. Effect of strengthening on surface defects (visual condition)

The results are thus close to the expected ones: $75 \%$ score 1 , and $25 \%$ score 2 (not fully perfect condition registered only one year after construction refers to quality problem during realisation). In Table 1, a generally spectacular reduction can be seen in the rut depth of trial sections after resurfacing. It can be seen that the relatively thick new asphalt layers could reduce rut depth to

Table 1. Reduction in rut depth as a consequence of new pavement layers

\begin{tabular}{|c|c|c|c|c|}
\hline Trial section & $\begin{array}{c}\text { Year of } \\
\text { intervention }\end{array}$ & $\begin{array}{l}\text { Previous rut depth } \\
\text { [mm] }\end{array}$ & $\begin{array}{c}\text { New rut depth } \\
{[\mathrm{mm}]}\end{array}$ & $\begin{array}{l}\text { Reduction in rut depth } \\
\qquad[\mathrm{mm}]\end{array}$ \\
\hline Road 63, 28+000-28+500 & 2000 & 10.0 & 2.0 & 8.0 \\
\hline Road 63, 28+000-28+500 & 2010 & 8.2 & 4.2 & 4.0 \\
\hline Road 33,. 71+000-71+500 & 1999 & 12.6 & 1.5 & 11.1 \\
\hline Road 47, 90+000-90+500 & 1996 & 6.1 & 3.0 & 3.1 \\
\hline Road 61, 40+000-40+500 & 1997 & 5.0 & 2.2 & 2.8 \\
\hline Road 3401, 15+000-15+500 & 1995 & 1.5 & 1.0 & 0.5 \\
\hline Road 53107, 2+000-2+500 & 2001 & 7.5 & 3.5 & 4.0 \\
\hline Road 6, 234+000-234+500 & 1992 & 2.4 & 1.5 & 0.9 \\
\hline Road 33, 20+000-20+500 & 1997 & 6.8 & 3.1 & 3.7 \\
\hline Road 3, 104+100-104+600 & 1995 & 4.8 & 2.1 & 2.7 \\
\hline Road 4, 172+000-172+500 & 1997 & 14.8 & 2.0 & 12.8 \\
\hline Road 11, 53+000-53+500 & 2000 & 6.6 & 2.0 & 2.6 \\
\hline Road 30, 50+000-50+500 & 1994 & 5.3 & 1.9 & 3.4 \\
\hline Road 50, 50+000-50+500 & 1998 & 6.6 & 2.0 & 4.6 \\
\hline Road 75, 49+700-60+200 & 2002 & 6.6 & 5.1 & 1.5 \\
\hline Road 4, 59+000-59+500 & 2004 & 8.3 & 1.9 & 6.4 \\
\hline Road 44, 105+000-105+500 & 2004 & 7.0 & 2.0 & 5.0 \\
\hline Road 89, 8+900-9+400 & 2004 & 5.9 & 1.9 & 4.0 \\
\hline Road 4407, 2+000-2+500 & 2004 & 8.0 & 2.0 & 6.0 \\
\hline Road 8, 117+000-117+500 & 2005 & 13.7 & 1.7 & 12.0 \\
\hline Road $1113,15+000-15+500$ & 2005 & 4.3 & 2.0 & 2.3 \\
\hline Road 5606, 0+000-0+500 & 2009 & 8.0 & 1.0 & 7.0 \\
\hline Mean values & & 7.0 & 2.2 & 4.8 \\
\hline
\end{tabular}


Table 2. Reduction in rut depth as a consequence of new thin pavement layers

\begin{tabular}{|c|c|c|c|c|}
\hline Trial section & $\begin{array}{c}\text { Year of } \\
\text { intervention }\end{array}$ & $\begin{array}{l}\text { Previous rut depth } \\
\text { [mm] }\end{array}$ & $\begin{array}{c}\text { New rut depth } \\
{[\mathrm{mm}]}\end{array}$ & $\begin{array}{l}\text { Reduction in rut depth } \\
\qquad[\mathrm{mm}]\end{array}$ \\
\hline Road 4, 59+000-59+500 & 1996 & 13.2 & 7.5 & 5.7 \\
\hline Road 8, 117+000-117+500 & 1999 & 9.8 & 6.5 & 3.3 \\
\hline Mean values & & 11.5 & 7.0 & 4.5 \\
\hline
\end{tabular}

Table 3. Increase in macro texture of trial sections due to surface dressing

\begin{tabular}{|c|c|c|c|c|}
\hline Trial section & Year of intervention & Previous macro texture & New macro texture & Increase in macro texture \\
\hline Road 32, 7+000-7+500 & 1994 & 0.21 & 0.99 & 0.78 \\
\hline Road 5606, 0+000-0+500 & 2000 & 0.18 & 0.34 & 0.16 \\
\hline Road 5702, 18+000-18+500 & 2000 & 0.43 & 0.51 & 0.08 \\
\hline Road $1113,15+000-15+500$ & 2000 & 0.10 & 0.27 & 0.09 \\
\hline Road 3102, 3+000-3+500 & 1995 & 0.21 & 0.31 & 0.10 \\
\hline Road 31106, 0+000-0+500 & 1995 & 0.53 & 0.96 & 0.43 \\
\hline Road $87,45+400-45+900$ & 1993 & 0.22 & 0.46 & 0.24 \\
\hline Road $87,55+400-55+900$ & 1999 & 0.46 & 0.42 & -0.04 \\
\hline Road 48, 25+000-25+500 & 1993 & 0.34 & 0.37 & 0.03 \\
\hline Road 89, 11+800-12+300 & 1994 & 0.34 & 0.47 & 0.13 \\
\hline Road $88,5+000-5+500$ & 1993 & 0.20 & 0.47 & 0.27 \\
\hline Mean values & & 0.29 & 0.42 & 0.21 \\
\hline
\end{tabular}

Table 4. Increase in micro texture of trial sections due to surface dressing

\begin{tabular}{|c|c|c|c|c|}
\hline Trial section & Year of intervention & Previous macro texture & New macro texture & Increase in macro texture \\
\hline Road 32, 7+000-7+500 & 1994 & 0.14 & 0.55 & 0.41 \\
\hline Road 5606, 0+000-0+500 & 2000 & 0.17 & 0.25 & 0.08 \\
\hline Road $5702,18+000-18+500$ & 2000 & 0.18 & 0.26 & 0.08 \\
\hline Road $1113,15+000-15+500$ & 2000 & 0.14 & 0.21 & 0.07 \\
\hline Road 3102, 3+000-3+500 & 1995 & 0.12 & 0.19 & 0.07 \\
\hline Road 31106, 0+000-0+500 & 1995 & 0.23 & 0.45 & 0.22 \\
\hline Road $87,45+400-45+900$ & 1993 & 0.16 & 0.26 & 0.10 \\
\hline Road $87,55+400-55+900$ & 1999 & 0.25 & 0.38 & 0.13 \\
\hline Road 48, 25+000-25+500 & 1993 & 0.20 & 0.19 & -0.01 \\
\hline Road 89, 11+800-12+300 & 1994 & 0.22 & 0.27 & 0.05 \\
\hline Road 88, 5+000-5+500 & 1993 & 0.14 & 0.24 & 0.10 \\
\hline Mean values & & 0.18 & 0.30 & 0.12 \\
\hline
\end{tabular}

1.0 to $3.0 \mathrm{~mm}$ and this more or less regardless of the previous rut depth value. At the same time, if only a thin asphalt layer is applied (Table 2) on the pavement affected by significant rutting (9.8 to $13.2 \mathrm{~mm}$ ), the decrease in rutting is rather limited as 6.5 to $7.5 \mathrm{~mm}$ rut depth values were recorded.

The influence of surface dressing on the macro and micro texture of trial sections is shown in Tables 3 and 4. Some conclusions are:

- it can generally be observed that surface dressing can improve macro texture slightly more compared to micro texture (in case of trial section monitoring, dimensionless macro and micro texture parameters measured by laser RST were used),

- increase in macro roughness amounted to 0.10 to 0.20 ; however, two extreme cases were also registered by improvements of 0.43 and 0.78 in pavement surface macro roughness,

- in case of a trial section, a minor (0.04) macro texture decrease was registered after surface dressing; however, in this case, the previous value was rather high (0.46),

- the typical improvement in micro roughness was between 0.05 and 0.13; however, an increase ranging from 0.22 and 
0.41 was also registered (the last one was found on the trial section with highest improvement in surface macro roughness),

- surface dressing resulted in a minor decrease in micro roughness (0.01), where the negative tendency, similar to that mentioned before, was registered for macro roughness.

\section{Deterioration trends before and after rehabilitation}

The deterioration of pavements after rehabilitation, i.e. after strengthening without milling the old layer(s), is dependent on various partly controversial factors including, among others, the thickness and quality of new asphalt layer(s), the quality of remaining old pavement layers, and the traffic progression (growth) factors. The actual deterioration (and duration of new life cycle) originates from the combination of influencing parameters. The deterioration features of two typical trial sections are compared - as case studies - before and after the condition improving intervention (pavement strengthening or surface dressing).

Deterioration curves for a main road trial section with asphalt concrete wearing course, showing the trends before and after a pavement strengthening done in 2002, are presented in Figure 2 (in this case, a $5 \mathrm{~cm}$ asphalt concrete overlay was applied as strengthening after the surface defects - mainly cracks and potholes - had reached the intervention level).The following statements can be made after comparison of deterioration curve "parts" of various condition parameters before and after the intervention:

- surface defects characterized by Road Master, 5-level visual inspection reached the worst (5) score in the "before" life cycle already at the age of 11 years (the trial section had been constructed in 1989), while the deterioration during "after" life cycle is considerably slower showing still a medium condition level (score 3) after 12 years in 2014;

- the average rut depth of the section in 2 years before the pavement strengthening - at the age of 11-13 years - was around $8 \mathrm{~mm}$, the same level was attained after 10 years in the "after" life cycle proving the similarity of the two rut depth progression trends;

- trend of IRI values is practically not influenced by the pavement rehabilitation, since it is continuously around 2 $\mathrm{m} / \mathrm{km}$ proving that unevenness constitutes very rarely the critical condition parameter of Hungarian main roads with relatively thick pavement structure.

- Figure 3 presents the deterioration curves of a trial section on a Hungarian main road showing the trends before and after a pavement strengthening done in 2000 (6 cm asphalt concrete overlay was built without recycling old wearing course after surface defects and rutting had overcome relevant intervention levels). The following statements can be made when comparing the deterioration curve "parts" of various condition parameters before and after the intervention:
- surface defects reached the worst (5) score in the "before" life cycle already at the age of 17 years (the trial section was constructed in 1981), while the deterioration during "after" life cycle is similar showing a poor condition level (score 4) after 14 years in 2014;

- the average rut depth on the section one year before strengthening - at the age of 18 years - was around $13 \mathrm{~mm}$; a similar level was attained after 12 years in the "after" life cycle proving accelerated rut depth progression trend after rehabilitation;

- the trend of IRI values is practically unaffected by the pavement rehabilitation, since it continuously remains around $2 \mathrm{~m} / \mathrm{km}$.

Section 75

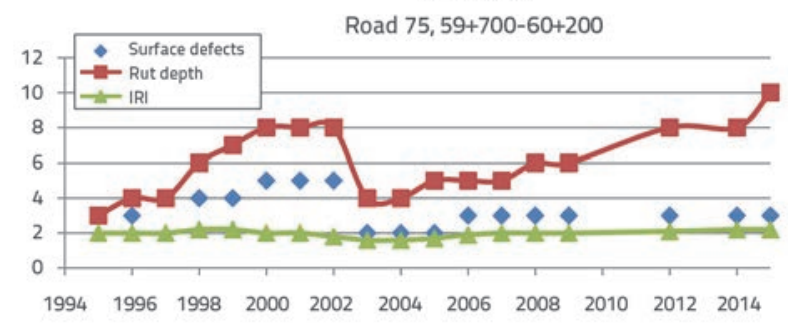

Figure 2. Deterioration curve for a trial section before and after pavement strengthening in 2002

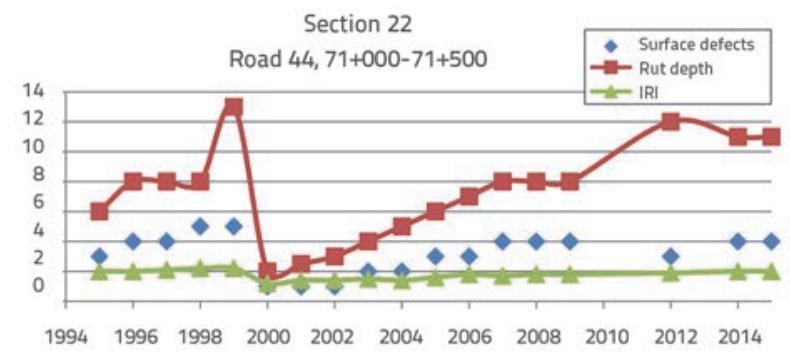

Figure 3. Deterioration curve for a trial section before and after pavement strengthening in $\mathbf{2 0 0 0}$

Deterioration curves for a trial section on a heavilytrafficked main road with asphalt concrete wearing course, showing the trends before and after the 1996 and 2007 pavement strengthening, are shown in Figure $416 \mathrm{~cm}$ asphalt concrete overlay was applied as strengthening technique after surface defects - mainly cracks, potholes and rutting - reached the intervention level). The following statements can be made:

- surface defects reached the worst (5) score in the "before" life cycle already at the age of 8 years (the trial section was built in 1985), while the deterioration during the first "after" life cycle is definitely slower showing a poor condition level (score 4) after 11 years in 2007; the trend in the third life cycle is also comparable to the previous one since a moderate condition level (score 3 ) was reached at the age of 7 years in 2015; 
- the average rut depth at the section one year before the strengthening - at the age of 11 years - was $15 \mathrm{~mm}$; after the first rehabilitation, slower deterioration was attained with only $11 \mathrm{~mm}$ rut depth after 11 years; in the second "after" life cycle the rut depth progression trend was comparable to the previous one reaching $9 \mathrm{~mm}$ after 7 years;

- the trend of IRI values is practically unaffected by pavement rehabilitation, since it continuously remains a little below 2 $\mathrm{m} / \mathrm{km}$.

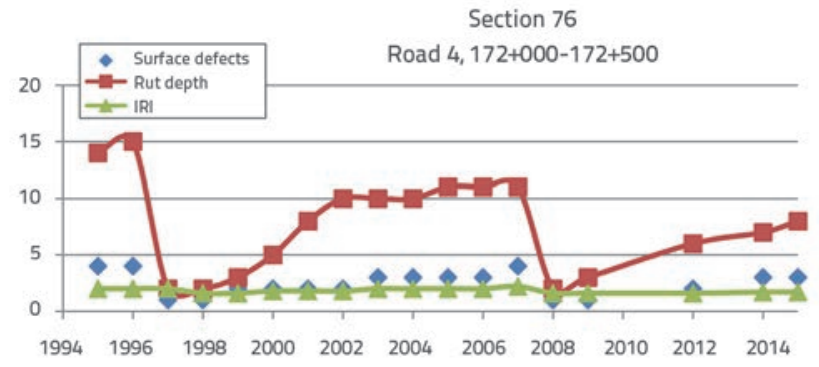

Figure 4. Deterioration curve for a trial section before and after pavement strengthening in 1996 and 2007

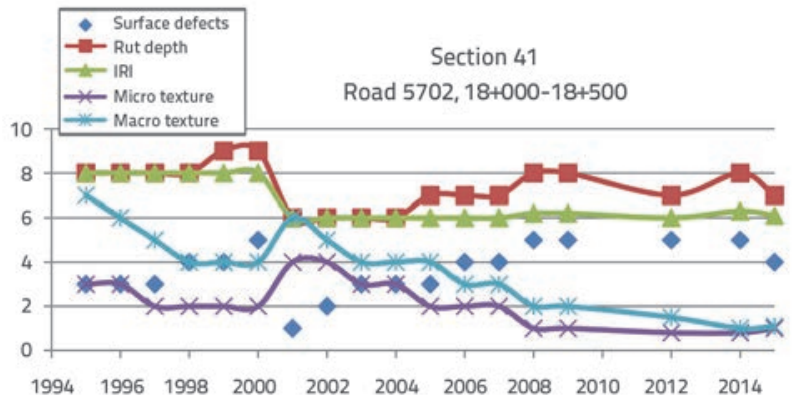

Figure 5. Deterioration curve for a trial section before and after surface dressing in $\mathbf{2 0 0 0}$

Figure 5 shows surface defects, rut depth, IRI, micro roughness, and the macro roughness deterioration curve, for a trial section on a secondary road with the asphalt macadam wearing course, before and after surface dressing conducted in 2000 (double bituminous emulsion surface dressing was also conducted in 1992 due to the unacceptably low surface macrotexture and the excessively high number of longitudinal and transverse cracks). The following statements can be made about these curves:

- during the "before" life cycle, the worst (5) score of surface defects was reached in 2000, at the age of 8 years while, in the "after" life cycle, the same level was attained at the age of 7 years (2008), proving a similar deterioration speed;
- 8-9 mm rut depth could be measured at the age of 8-9 years, at the end of the "before" life cycle; similarly, 7-8 years were needed in the "after" life cycle to attain the same level (the surface dressing reached, not surprisingly, just a $3 \mathrm{~mm}$ reduction in rut depth);

- the second period of the "after" life cycle was characterized by a rather high $(8 \mathrm{~m} / \mathrm{km})$ average IRI-value; surface dressing can reduce the IRI by $2 \mathrm{~m} / \mathrm{km}$, and, a bit surprisingly, this 6 $\mathrm{m} / \mathrm{km}$ value was measured, almost unchanged, during the first 13 years of the "after" life cycle; thus, a significant improvement can be seen in the second life cycle (the reason can be the effective and durable waterproofing effect of the double surface dressing);

- the micro texture parameter reached a rather poor level (0.2) at the age of 6-8 years, at the end of the "before" life cycle; surface dressing improved to 0.4 , and deteriorated to 0.2 in 4-5 years, and even to an extremely poor level of 0.1 in 7-8 years, indicating that surface dressing could not fulfil one of its main tasks, durable improvement of surface micro texture;

- the macro texture parameter reached the level of 0.4 at the age of 6-8 years, at the end of the "before" life cycle; surface dressing improved its value to the reasonable level of 0.6 but deteriorated to 0.4 in 2-3 years, and to a poor level of 0.2 in 7-8 years, and even to an extremely poor level of 0.1 in 1213 years, proving a worse behaviour after surface dressing.

\section{Concluding remarks}

Based on the results of the trial section case studies (Figures 3 to 6), the following general statements can be made:

- typical condition parameters for Hungarian asphalt pavements (necessitating rehabilitation action due to very poor condition) are surface defects and/or rut depth

- the actual condition of a critical parameter at the time of rehabilitation is usually below the "official" intervention level specified in relevant standards or technical directives, which is due to typical shortage of financing available in road sector

- the actual condition improvement with regard to various parameters mainly depends on the quality level of the old structure, and on the design and construction features; the "rehabilitated" condition very rarely reaches that of the original, newly built pavement

- deterioration trends before and after pavement rehabilitation are typically similar; however, local extreme traffic, design, construction, maintenance, and/or climatic conditions can induce basic differences between them; accelerated deterioration in the second life cycle is rather rare. 


\section{REFERENCES}

[1] Karoliny, M., Gáspár, L.: Investigation and design of durable pavement structure rehabilitation. Journal of Pavement Engineering \& Asphalt Technology, 16 (2015) 1, pp. 30-45

[2] Bakó, A., Gáspár, L.: PMS models in Hungary. CD-ROM Proceedings of $1^{\text {st }}$ European Pavement Management Systems Conference, Budapest, pp. 10, 2000.

[3] Robinson, R., Danielson, U., Snaith, M.: Road Maintenance Management. Concepts and Sys-tems. MacMillan Press Ltd., pp. 291, 1998, https://doi.org/10.1007/978-1-349-14676-5

[4] Gáspár, L.: Highway performance modelling. Proceedings of International Conference on Develop-ments in Road Engineering. National Institute of Technology, Rourkela, India, pp. 24-36, 2010.

[5] Bakó, A., Csicsely-Tarpay, M., Gáspár, L., Szakos, P.: The Development and Application of a Combined Highway-motorway Pavement Management System in Hungary. 4th International Con-ference on Managing Pavements. Durban, South Africa Proceedings, 3 (1998), pp. 1091-1105.

[6] Gáspár, L.Jr.: Ein netzbezogenes Managementsystem für die Strassenerhaltung in Ungarn. Strasse + Autobah, 8 (1992), pp. 490-495.

[7] Gáspár, L.Jr., Bakó, A.: Le systéme hongrois de gestion de I'entretien. Revue Générale des Routes et des Aérodromes, 710 (1993), pp. 34-36.

[8] Gáspár, L.Jr.: Compilation of First Hungarian Network-Level Pavement Management System. Transportation Research Record 1455 Pavement Management Systems.National Academy Press. Washington, pp. 22-30, 1994.

[9] Csicsely-Tarpay, M., Bakó, A., Gáspár, L., Marton, L.: Hungarian Pavement Management System for the Road Network of a City. Second International Conference on Road and Airfield Pavement Technology, Singapore, 2 (1995), pp. 692-700.

[10] Talvitie, A., Olsonen, R.: Selecting Asphalt Concrete Condition States for Finland's Highways. Proceedings of the $67^{\text {th }}$ Annual Meeting of the TRB, Washington, pp. 38, 1988.

[11] Bakó, A., Klafszki, E., Szántai, T., Gáspár L.: Optimization Techniques for Planning Highway Pavement Improvements, Annal of Operations Research, 58 (1995), pp. 55-66, https://doi. org/10.1007/BF02032310

[12] Männistö, V., Tapio, R.: Infrastructure Management System. In: Transportation Research Record 1445, Transportation Research Board, pp. 132-138, 1994.
[13] Haas, R., Hudson, W.R., Zaniewski, J.: Modern Pavement Management. Krieger Publishing Company, Malabar (USA), pp. 583, 1994.

[14] Gáspár, L., Karoliny, M.: Investigation and design of durable pavement structure rehabilitation. LAP Lambert Academic Publishing, Saarbrücken, pp. 101, 2015.

[15] Mallick, R.B., El-Korchi, T.: Pavement Engineering. Principles and Practice. CRC Press Taylor \& Francis Group, Boca Raton, USA, pp. 511,2009

[16] Gáspár, L., Veeraragavan, A., Bakó, A.: Comparison of Road Pavement Performance Modelling of India and Hungary. ActaTechnicaJaurensis, 2 (2009) 1, pp. 35-55, 2009.

[17] Gáspár, L.: Lifetime engineering for roads. (Keynote lecture), $2^{\text {nd }}$ International Conference on Road and Rail Infrastructure - CETRA 2012 (ed. Lakusic, S.), Dubrovnik, Croatia, pp. 25-34, 2012.

[18] Gáspár, L., Bencze, Zs.: Experimental sections in the Hungarian road management, $3^{\text {rd }}$ International Conference on Road and Rail Infrastructure - CETRA 2014 (ed. Lakusic, S.), Split, Croatia, pp. 183-188, 2014.

[19] Gáspár, L.: Highway Performance Modelling in Hungary. The International Journal of Pavement Engineering \& Asphalt Technology, 1 (2000) 1, pp. 44-56

[20] Boromisza, T., Nemesdy, E.: Measurement guide for trial sections. Research team report of Hungarian Scientific Association for Transport, 1990. (In Hungarian)

[21] Paterson, W.D.: Prediction of Road Deterioration and Maintenance Effects: Theory and Quan-tification. Volume II, World Bank, Washington, 1986

[22] stattrek.com/statistics/charts/boxplot.aspx?Tutorial=AP

[23] Gáspár, L.: Actual condition improving effect of major pavement maintenance treatments. $2^{\text {nd }}$ European Pavement and Asset Management Conference, Berlin, CD-ROM Proceedings, pp. 12, 2004.

[24] Gáspár, L.: Actual efficiency of road pavement rehabilitation, $4^{\text {th }}$ International Conference on Road and Rail Infrastructure - CETRA 2016 (ed. Lakusic, S.), Sibenik, Croatia, pp. 181-186, 2016.

[25] Gáspár, L.: Road management. Academy Press, Budapest, pp. 324, 2003. (In Hungarian)

[26] Gáspár, L.: Hungarian pavement performance models. $9^{\text {th }}$ International Conference on Asphalt Pavements, Copenhagen, pp. 8, 2002. 